\title{
An ecological study of the association between environmental indicators and early childhood caries
}

\author{
Morenike Oluwatoyin Folayan ${ }^{1 *} \mathbb{D}$, Maha El Tantawi², Balgis Gaffar ${ }^{3}$, Robert J. Schroth ${ }^{4}$, Jorge L. Catillo ${ }^{5}$, \\ Ola B. Al-Batayneh ${ }^{6}$, Arthur Kemoli ${ }^{7}$, Aída Carolina Medina Díaz ${ }^{8}$, Verica Pavlic ${ }^{9}$ and Maher Raswhan ${ }^{10,11}$ for \\ Early Childhood Caries Advocacy Group
}

\begin{abstract}
Objectives: A prior study described the association between ecosystem vitality, environmental health, and early childhood caries (ECC). The objective of this study was to determine the association between 24 global environmental indicators and ECC in 3-5-year-old children.

Results: In 61 countries, 55.5\% of 3-5-year-old children had ECC. Eight factors had a small effect-size association with ECC: percentage of area that is marine-protected (partial eta squared; $\eta^{2}=0.03$ ); species habitat index $\left(\eta^{2}=0.06\right.$ ); percentage of tree-cover loss $\left(\eta^{2}=0.03\right)$; regional marine trophic index $\left(\eta^{2}=0.03\right)$; total carbon dioxide emission intensity $\left(\eta^{2}=0.03\right)$; methane emission intensity $\left(\eta^{2}=0.04\right)$; nitrous oxide emission intensity $\left(\eta^{2}=0.06\right)$; and sulfur dioxide emission intensity $\left(\eta^{2}=0.03\right)$. Regression analysis revealed that two of these factors were significantly associated with the prevalence of ECC: methane emission intensity was inversely associated with ECC prevalence $(B=-0.34,95 \%$ $C l=-0.66,-0.03 ; p=0.03)$, and nitrous oxide had a direct association with $E C C$ prevalence $(B=0.35,95 \% C l=0.04$, $0.67 ; p=0.03)$.
\end{abstract}

Keywords: Environmental performance indicators, Early childhood caries, Nitrous oxide emission, Methane emission

\section{Introduction}

Human health benefits from ecosystem biodiversity and from experiencing nature. Strong evidence links biodiversity, nature exposure, and human health [1]. Few empirical studies, however, have assessed possible links of the ecosystem and oral health. One such study investigated the association between ecosystem vitality, environmental health, and early childhood caries (ECC), which is any caries experience of the primary teeth in children $<72$ months of age [2,3]. The study identified

\footnotetext{
${ }^{*}$ Correspondence: toyinukpong@yahoo.co.uk

${ }^{\dagger}$ Morenike Oluwatoyin Folayan and Maha El Tantawi contributed equally to this work

${ }^{1}$ Department of Child Dental Health, Obafemi Awolowo University, Ile-Ife, Osun State, Nigeria

Full list of author information is available at the end of the article
}

an inverse and significant association between ECC in 3-5-year-olds and ecosystem vitality, and a direct but non-significant association between ECC prevalence and environmental health [3]. However, the study determined these associations by using composite ecosystem vitality and environmental health scores.

Environmental performance indicators include four that measure ecosystem vitality: (1) biodiversity and habitat (protected areas and species), (2) forests (tree cover loss), (3) fisheries (fish stocks), and (4) climate and energy (trend in carbon intensity and carbon dioxide emissions); and three indicators that measure environmental health: air quality, water and sanitation, and exposure to heavy metals.

A few publications have postulated a link between climate change and oral health, including ECC [6], but there

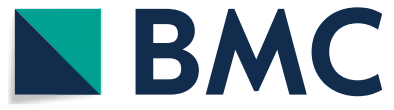

(c) The Author(s) 2020. This article is licensed under a Creative Commons Attribution 4.0 International License, which permits use, sharing, adaptation, distribution and reproduction in any medium or format, as long as you give appropriate credit to the original author(s) and the source, provide a link to the Creative Commons licence, and indicate if changes were made. The images or other third party material in this article are included in the article's Creative Commons licence, unless indicated otherwise in a credit line to the material. If material is not included in the article's Creative Commons licence and your intended use is not permitted by statutory regulation or exceeds the permitted use, you will need to obtain permission directly from the copyright holder. To view a copy of this licence, visit http://creativecommons.org/licenses/by/4.0/. The Creative Commons Public Domain Dedication waiver (http://creativecommons.org/publicdomain/zero/1.0/) applies to the data made available in this article, unless otherwise stated in a credit line to the data. 
are no empirical data on the link between the seven environmental performance indicators. Links have been suggested, though, between climate change, alterations in the concentration of greenhouse gases, and health problems [7]. The greenhouses gases (carbon dioxide, methane, water vapor, surface-level ozone, nitrous oxides, and fluorinated gases) absorb infrared radiation emitted from the earth's surface and re-radiate it back to the earth's surface, thereby warming the earth [8]. Global warming is associated with food shortages and the spread of diseases and pandemics, and it may aggravate cardiovascular and respiratory problems [9]. Food shortage can result in shortage of protein, energy, and micronutrients, which can lead to oral health problems, including caries [10]. Less is known about the direct impact of these gases on oral health.

Use of the environmental performance indicators is intended to capture the impact of various factors that interact to affect the health of the environment. A previous study [1] showed that the impact of some indicators seemed stronger and opposite in direction to other indicators. A closer look and more detailed analysis of the environmental indicators may shed light on how ECC and the seven indicators of environmental performance are associated. Therefore, this study aimed to investigate the association between the global indicators for environmental performance and ECC in 3-5-year-old children.

\section{Main text \\ Methods}

This was an ecological study that studied the on the association between ECC in 3-5-year-old children and the environment using environmental indicators [11]. The study covered the period from 2007 to 2017.

ECC data for children aged 3-5 years old were available for 85 United Nations States. These estimates were extracted from studies published between 2007 and June 2017 and indexed in MEDLINE, Web of Science, Scopus, and Google Scholar without language restriction. Nationally representative data were used to the greatest extent possible. Estimates from several studies were combined at the country level. The percentage of affected children was calculated as the number of children with ECC in all relevant studies divided by the total number of children examined and multiplied by 100 [11]. ECC was defined as the presence of one or more decayed, missing-due-tocaries, or cavitated non-cavitated carious tooth in a child younger than 6 years of age [2].

Environmental indicators data from the Yale Center for Environmental Law and Policy were used [4]. These data are ratings of the performance of countries on several environmental indicators arranged under two domains: environmental health (including three categories with six indicators) and ecosystem vitality (including seven categories with 18 indicators), resulting in a total of 24 indicators that describe the quality of the environment from various aspects. The values of the 24 indicators are reported at the country level on a score ranging from 0 to 100, with higher scores indicating better performance. The definitions of the indicators are presented in Additional file 1: Table S1. Data availability for different indicators varied, ranging from an indicator with data for 131 countries to indicators with data from 175 countries; 90 countries had complete data for the 24 indicators.

The data gathered were analyzed, and descriptive statistics (frequencies, percentages, means, and standard deviations) were calculated. Linear regression analysis was used to assess the association between the outcome variable (percentage of 3-5-year-old children with ECC) and the explanatory variables (environmental performance indicators), controlling for income level based on the gross national income (GNI). Countries were classified by GNI into low-income countries (GNI US\$1025 or less), lower middle-income countries (GNI US\$1026 to US\$3995), upper middle-income countries (GNI US\$3996 to US\$12,475), and high-income countries (GNI US\$12,476 or more [12].

Two sets of multivariable linear regression models were developed. For Model 1, each environmental performance indicator was entered one at a time with adjustment for income level. Indicators with partial eta squared $\left(\eta^{2}\right)$ of at least small-effect size $\left(\eta^{2}=0.02\right)$ [13] were entered into Model 2, where they were all mutually adjusted for in addition to the income level. Regression coefficients (B), 95\% confidence intervals $(\mathrm{CI}), \mathrm{p}$ values, and partial eta squared $\left(\mathrm{n}^{2}\right)$ were calculated. SPSS version 23.0 was used. Significance was set at $5 \%$.

\section{Results}

Combined ECC and environmental performance indicators data were available for 61 countries (Additional file 2: Table S2). Of these, two (3.3\%) were low-income countries, 14 (23\%) were low middle-income countries, 18 (29.5\%) were upper middle-income countries, and 27 (44.3\%) were high-income countries. The mean percentage of children with ECC was $55.5 \%$. The mean percentage of environmental performance indicators ranged from a minimum of $22.3 \%$ for Tree Cover Loss to a maximum of $87.1 \%$ for Marine Protected Areas, as indicated in Table 1.

Table 2 reports the association between individual environmental performance indicators and ECC in 3-5-year-old children adjusted for country income level in Model 1. Eight factors had at least a small-effect size association with ECC in 3-5-year-old children: percentage of marine protected areas $\left(\eta^{2}=0.03\right)$, species 


\begin{abstract}
Table 1 Distribution environmental performance indicators and early childhood caries in 3-5-year-old children in the 61 countries included in the study
\end{abstract}

\begin{tabular}{ll}
\hline Factors & $\begin{array}{l}\text { Percent score } \\
\text { Mean (SD) }\end{array}$ \\
\hline Early childhood caries prevalence & $55.54(22.14)$ \\
Household solid fuels & $61.40(32.23)$ \\
PM2.5 exposure & $81.82(25.61)$ \\
PM2.5 exceedance & $82.63(22.36)$ \\
Sanitation & $65.27(28.15)$ \\
Drinking water & $64.55(28.18)$ \\
Lead exposure & $63.07(23.91)$ \\
Marine protected areas & $87.05(14.49)$ \\
Terrestrial biome protection (National) & $77.71(27.00)$ \\
Terrestrial biome protection (Global) & $76.93(27.61)$ \\
Species protection index & $79.56(23.86)$ \\
Protected area representativeness index & $48.34(24.23)$ \\
Species habitat index & $77.36(18.40)$ \\
Tree cover loss & $22.29(20.07)$ \\
Fish stock status & $60.64(23.93)$ \\
Regional marine trophic index & $50.94(25.33)$ \\
$\mathrm{CO}_{2}$ emission intensity - total & $47.96(17.09)$ \\
$\mathrm{CO}_{2}$ emission intensity - power & $46.87(20.95)$ \\
Methane emission intensity $_{\mathrm{N}_{2} \mathrm{O} \text { emission intensity }}$ & $68.48(19.44)$ \\
Black carbon emission intensity $_{2}$ emission intensity & $57.71(19.17)$ \\
NOX emission intensity $_{\text {Wastewater treatment }}$ & $55.93(21.32)$ \\
Sustainable nitrogen management index & $53.66(25.18)$ \\
& $50.91(23.73)$ \\
& $74.41(30.20)$ \\
& $38.03(17.35)$ \\
\hline
\end{tabular}

habitat index $\left(\eta^{2}=0.06\right)$, percentage of tree cover loss $\left(\eta^{2}=0.03\right)$, regional marine trophic index $\left(\eta^{2}=0.03\right)$, total carbon dioxide emission intensity $\left(\eta^{2}=0.03\right)$, methane emission intensity $\left(\eta^{2}=0.04\right)$, nitrous oxide emission intensity $\left(\eta^{2}=0.06\right)$, and sulfur dioxide emission intensity $\left(\eta^{2}=0.03\right)$.

These eight indicators were entered into Model 2, where they were mutually adjusted in addition to adjusting for income level. Model 2 explained $31 \%$ of the variation in the percentage of 3-5-year-old children with ECC. The model revealed that four factors had an association with the prevalence of ECC of at least small-effect size: species habitat index $\left(\eta^{2}=0.02\right)$, regional marine trophic index $\left(\eta^{2}=0.02\right)$, methane emission intensity $\left(\eta^{2}=0.09\right)$, and nitrous oxide emission intensity $\left(\eta^{2}=0.09\right)$.

Two indicators (species habitat index and methane emission intensity) were inversely associated with the prevalence of ECC. Higher species habitat index was non-significantly associated with lower percentage of children affected with $\mathrm{ECC}(\mathrm{B}=-0.15,95 \% \mathrm{CI}=-0.48$,
$0.19 ; \mathrm{p}=0.39)$. Greater methane emission intensity was significantly associated with lower percentage of ECCaffected children $(B=-0.34,95 \% \mathrm{CI}=-0.66,-0.03$; $\mathrm{p}=0.03)$.

Two indicators (regional marine trophic index and nitrous oxide emission intensity) were directly associated with the prevalence of ECC. Higher regional marine trophic index was non-significantly associated with greater percentage of ECC-affected children $(B=0.09$, 95\% CI $=-0.11,0.29 ; \mathrm{p}=0.39)$. Greater nitrous oxide emission intensity was associated with significantly higher percentage of 3-5-year-old ECC-affected children $(B=0.35,95 \% C I=0.04,0.67 ; p=0.03)$.

\section{Discussion}

Our analysis revealed that methane and nitrous oxide emission intensities were risk indicators for ECC in 3-5-year-old children, though the associations were in opposite directions: methane emissions were associated with lower prevalence of ECC, and nitrous oxide emissions were associated with higher prevalence of ECC. This study provides evidence that some greenhouse gases also may be associated with poor oral health and are risk indicators for ECC in 3-5-year-old children, although with small effect.

Methane and nitrous oxide are two of the three most important long-lived greenhouse gases that contribute to global warming - the third being carbon dioxide [14]. Greenhouse gases are reported to have direct effects on public health, such as by causing heat-related morbidity and mortality and increasing the risk for vector-borne and food-borne diseases [15], with negative implications for the general health and wellbeing of children [16]. Perhaps knowing the relationships between indicators of environmental performance and ECC will foster more holistic approaches to improving children's oral health.

Methane emission levels are generally higher in developing countries than in developed countries [17]. Sources of methane are mainly human activities related to animal agriculture and rice production [18-21], which account for $53 \%$ of the total anthropogenic methane emissions [22]. Higher methane emissions are frequently found in agricultural settings, where the diet is likely comprised of more locally sourced fruits, vegetables, grains, and meats and comprised less of refined carbohydrates. This dietary lifestyle would contribute to a lower prevalence of ECC [23] if ECC is caused indirectly by the surrounding agricultural environment and the lower socioeconomic status of people living in these agricultural areas rather than to a direct effect of this gas. However, a direct effect also is plausible: Methane has anti-inflammatory, antiapoptosis, and antioxidant properties through which it exerts protective biological and clinical effects [24], one 
Table 2 Association between ECC in 3-5-year-old children and environmental performance indicators controlling for income level

\begin{tabular}{|c|c|c|c|c|c|c|}
\hline \multirow[t]{2}{*}{ Indicators } & \multicolumn{3}{|l|}{ Model 1} & \multicolumn{3}{|l|}{ Model 2} \\
\hline & $\mathrm{B}(95 \% \mathrm{Cl})$ & $P$ value & $\eta^{2}$ & $\mathrm{~B}(95 \% \mathrm{Cl})$ & P value & $\eta^{2}$ \\
\hline \multicolumn{7}{|l|}{ Environmental health indicators } \\
\hline Household solid fuels & $-0.05(-0.32,0.23)$ & 0.74 & 0.002 & & & \\
\hline PM2.5 exposure & $-0.02(-0.23,0.19)$ & 0.86 & 0.001 & & & \\
\hline PM2.5 exceedance & $-0.02(-0.26,0.23)$ & 0.88 & $<0.0001$ & & & \\
\hline Sanitation & $0.01(-0.37,0.39)$ & 0.96 & $<0.0001$ & & & \\
\hline Drinking water & $-0.14(-0.52,0.24)$ & 0.46 & 0.01 & & & \\
\hline Lead exposure & $-0.01(-0.33,0.31)$ & 0.95 & $<0.0001$ & & & \\
\hline \multicolumn{7}{|l|}{ Ecosystem vitality indicators } \\
\hline Marine protected areas & $-0.23(-0.60,0.14)$ & 0.22 & 0.03 & $-0.05(-0.43,0.33)$ & 0.8 & 0.001 \\
\hline National terrestrial biome protection & $0.003(-0.20,0.21)$ & 0.98 & $<0.0001$ & & & \\
\hline Global terrestrial biome protection & $-0.01(-0.22,0.19)$ & 0.9 & $<0.0001$ & & & \\
\hline Species protection index & $-0.10(-0.34,0.14)$ & 0.42 & 0.01 & & & \\
\hline Protected area representativeness index & $-0.10(-0.33,0.13)$ & 0.39 & 0.01 & & & \\
\hline Species habitat index & $-0.28(-0.56,0.006)$ & 0.06 & 0.06 & $-0.15(-0.48,0.19)$ & 0.39 & 0.02 \\
\hline Tree cover loss & $-0.16(-0.42,0.10)$ & 0.23 & 0.03 & $-0.12(-0.41,0.18)$ & 0.43 & 0.01 \\
\hline Fish stock status & $-0.06(-0.28,0.16)$ & 0.6 & 0.005 & & & \\
\hline Regional marine trophic index & $0.13(-0.07,0.33)$ & 0.2 & 0.03 & $0.09(-0.11,0.29)$ & 0.39 & 0.02 \\
\hline Total $\mathrm{CO}_{2}$ emission intensity & $-0.22(-0.52,-0.09)$ & 0.16 & 0.03 & $-0.07(-0.42,0.28)$ & 0.7 & 0.003 \\
\hline $\mathrm{CO}_{2}$ Emission intensity - power & $-0.10(-0.35,0.15)$ & 0.41 & 0.01 & & & \\
\hline Methane emission intensity & $-0.20(-0.47,0.08)$ & 0.15 & 0.04 & $-0.34(-0.66,-0.03)$ & 0.03 & 0.09 \\
\hline $\mathrm{N}_{2} \mathrm{O}$ emission intensity & $0.24(-0.03,0.51)$ & 0.07 & 0.06 & $0.35(0.04,0.67)$ & 0.03 & 0.09 \\
\hline Black carbon emission liintensity & $-0.06(-0.34,0.21)$ & 0.64 & 0.004 & & & \\
\hline $\mathrm{SO}_{2}$ emission intensity & $-0.15(-0.36,0.07)$ & 0.18 & 0.03 & $-0.04(-0.29,0.20)$ & 0.71 & 0.003 \\
\hline NOX emission intensity & $-0.04(-0.26,0.18)$ & 0.72 & 0.002 & & & \\
\hline Wastewater treatment & $-0.005(-0.25,0.24)$ & 0.97 & $<0.0001$ & & & \\
\hline Sustainable nitrogen management index & $-0.09(-0.42,0.24)$ & 0.6 & 0.005 & & & \\
\hline
\end{tabular}

Model 1: including individual environmental performance indicators, one at a time, adjusted for income level; Model 2: including all environmental performance indicators, adjusted for income level; B: regression estimate, Cl: confidence interval, $\mathrm{\eta}^{2}=$ partial eta squared

of which may be reducing the risk for caries, as the findings of this study suggest.

On the other hand, nitrous oxide is emitted through land-use change and fertilizer production [25] and from industry [26]; the dominant sources are closely related to microbial-production processes in soils, sediments, and water bodies [27]. Emission levels of the gas are higher in developed countries than in developing countries [28]. Poor regulation of nitrous oxide in industrialized urban environments may be a factor accounting for an association between nitrous oxide emission levels and ECC [3].

The pathophysiology of how these gases affect the risk for caries is not known. We postulate, though, that the absorption of gases present in the environment by the oral microbiome is the pathway to ECC, as methane has a neutral pH [29], and nitrous oxide is a neutral oxide [30]. However, the oral environment's rich microbiome has high alkali-generating potential (urea and arginine to ammonia) that also can produce methane. The high alkali-methane rich oral environment may protect against caries [31]. A methane-rich environment may enhance oral absorption from the atmosphere [24], resulting in protective oral effects against caries. The pathway to increased caries risk in environments with high nitrous oxide emission levels is less clear. Caries requires the acidification of dental plaque that favors the emergence of an acidogenic and acid-tolerant (aciduric) microflora that promote caries formation [32]. Although nitrous oxide accumulates faster in oral cavities that have heavy accumulations of plaque [33], this does not explain how nitrous oxide in the environment is associated with the risk for ECC. Future studies will be needed to explain how these environmental indicators, measured at smaller administrative units, may promote or prevent the development of ECC. The 
results of such studies may enable control for various potential confounders, thereby leading to more robust conclusions about ECC-environment relationships.

\section{Limitations}

This study has limitations. It is an ecological study that may have fallacies resulting from the use of multiple aggregated data sets. We acknowledge that in ecological studies, correlations tend to be larger when associations are determined at the group level rather than at the individual level [29]. The data also are skewed towards high-income countries and upper middle-income countries, which may limit generalizability of the findings. The study also is cross-sectional, so inferences on causal relationships cannot be made.

\section{Supplementary information}

Supplementary information accompanies this paper at https://doi. org/10.1186/s13104-020-05321-W.

Additional file 1: Table S1. Definition of environmental indicators. Additional file 2: Table S2. Countries included in the study and their indicators.

\section{Abbreviations}

B: Regression coefficient; Cl: Confidence interval; ECC: Early Childhood Caries; EPI: Environmental performance index; GNI: Gross national income; HICs: High income countries; LICs: Low income countries; LMICs: Low middle income countries; $\mathbf{\eta}^{2}$ : Partial eta squared; UMICs: Upper middle-income countries.

\section{Acknowledgement}

Dr. Schroth holds a Canadian Institutes of Health Research Embedded Clinician Researcher salary award.

\section{Authors' contributions}

MOF conceptualized and designed the study, collected data, drafted the initial manuscript, and reviewed and revised the manuscript. MET designed the study, collected data, conducted the data analysis, critically reviewed and revised the manuscript for important intellectual content. BG, RJS, JC, OBA, AK, ACMA, VP, MR reviewed and revised the manuscript for important intellectual content. All authors read and approved the final manuscript.

\section{Funding}

No grants was available for study implementation.

\section{Availability of data and materials}

Study related materials are public data. All study related data are included in the supplemental file of this manuscript.

\section{Ethics approval and consent to participate}

Not applicable.

\section{Consent for publication}

Not applicable.

\section{Competing interests}

Morenike Oluwatoyin Folayan is a sectional editor of BMC Oral Health. Maha El Tantawi, Ola B Al-Batayneh and Arthur Kemoli are Associate Editors of BMC Oral Health.

\section{Author details}

${ }^{1}$ Department of Child Dental Health, Obafemi Awolowo University, Ile-Ife, Osun State, Nigeria. ${ }^{2}$ Department of Pediatric Dentistry and Dental Public
Health, Faculty of Dentistry, Alexandria University, Alexandria, Egypt. ${ }^{3}$ Department of Preventive Dental Sciences, College of Dentistry, Imam Abdulrahman Bin Faisal University, Dammam, Saudi Arabia. ${ }^{4}$ Department of Preventive Dental Science, Dr. Gerald Niznick College of Dentistry, Rady Faculty of Health Sciences, University of Manitoba, Winnipeg, MB, Canada. ${ }^{5}$ Department of Dentistry for Children and Adolescents, Universidad Peruana Cayetano Heredia, Lima, Peru. ${ }^{6}$ Preventive Dentistry Department, Jordan University of Science and Technology, PO Box 3030, Irbid 22110, Jordan. ${ }^{7}$ Department of Paediatric Dentistry and Orthodontics, University of Nairobi, Nairobi, Kenya. ${ }^{8}$ Pediatric Dentistry and Orthodontics Department, Universidad Central de Venezuela, Caracas, Venezuela. ${ }^{9}$ Department of Periodontology and Oral Medicine, Medical Faculty, University of Banja Luka, Banja Luka, Republic of Srpska, Bosnia and Herzegovina. ${ }^{10}$ Centre for Oral Bioengineering, Barts and the London, School of Medicine and Dentistry, Queen Mary University of London, Mile End Road, London E1 4NS, UK. ${ }^{11}$ Department of Conservative Dentistry, Faculty of Dentistry, Alexandria University, Alexandria, Egypt.

Received: 25 June 2020 Accepted: 30 September 2020 Published online: 07 October 2020

References

1. Sandifer PA, Sutton-Grier AE, Ward BP. Exploring connections among nature, biodiversity, ecosystem services, and human health and wellbeing: Opportunities to enhance health and biodiversity conservation. Ecosyst Serv. 2015;12:1-15.

2. Drury TF, Horowitz AM, Ismail Al, Maertens MP, Rozier RG, Selwitz RH. J Public Health Dent. 1999:59(3):192-7.

3. Folayan MO, El Tantawi M, Schroth RJ, Kemoli A, Gaffar B, Amalia R, et al. Association between Environmental Health, Ecosystem Vitality and Early Childhood Caries. Front Public Health. 2020;8:196.

4. Wendling ZA, Emerson JW, Esty DC, Levy MA, de Sherbinin A, et al.2018 Environmental Performance Index. Chapter 2: Indicator framework. New Haven, CT: Yale Center for Environmental Law \& Policy. 2018. Available at: https://epi.envirocenter.yale.edu/epi-report-2018/chapter-2-metho dology/10-indicator-framework. Accessed 30 Dec 2019.

5. Kemoli AM. Paediatric oral health and climate change. Edorium J Dent. 2019;7(100034):D01AK2019.

6. Khanna S. Climate Change and Oral Health: Current Challenges and Future Scope. Int J Environ Sci Dev. 2010;1(2):190-2.

7. National Institute of environmental health sciences. Health impact: climate and human health. https://www.niehs.nih.gov/research/programs/ geh/climatechange/health_impacts/index.cfm. Accessed: 5 Sept 2020.

8. Mann ME. Greenhouse gas. Britannica. Available at: https://www.brita nnica.com/science/greenhouse-gas. Accessed: 5 September 2020.

9. IBERDROLA. The consequences of the greenhouse effect: from desertification to floods. https://www.iberdrola.com/environment/greenhouse -effects-consequences-and-impacts\#: :text=CONSEQUENCES\%25200 F\%2520THE\%2520GREENHOUSE\%2520EFFECT\%2520ON\%2520H UMAN\%2520HEALTH\&text=In\%2520addition\%2520to\%2520the\%2520p roblems,more\%2520areas\%2520of\%2520the\%2520planet. Accessed: 5 Sept 2020.

10. Sheetal A, Hiremath VK, Patil AG, Sajjansetty S, Kumar SR. Malnutrition and its oral outcome-a review. J Clin Diagn Res. 2013;7(1):178-80.

11. El Tantawi M, Folayan MO, Mehaina M, et al. Prevalence and Data Availability of Early Childhood Caries in 193 United Nations Countries, 2007-2017. Am J Public Health. 2018;108(8):1066-72.

12. The World Bank Group. 2018. List of economies in 2018.

13. Watson P. Rules of thumb on magnitudes of effect sizes. 2019. https:// imaging.mrc-cbu.cam.ac.uk/statswiki/FAQ/effectSize. Accessed: 6 June 2020.

14. Tian $\mathrm{H}$, Chen $\mathrm{G}$, Lu C, et al. Global methane and nitrous oxide emissions from terrestrial ecosystems due to multiple environmental changes. Ecosyst Health Sustain. 2015;1(1):4. https://doi.org/10.1890/EHS14-0015.1.

15. Wiener RC, Sambamoorthi U, Shen C, Alwhaibi M, Findley P. Food Security and Unmet Dental Care Needs in Adults in the United States. J Dent Hyg. 2018:92(3):14-22.

16. Bi P, Hansen A. Carbon emissions and public health: an inverse association? Lancet Planet Health. 2018;2(1):e8-9. 
17. Wei T, Dong W, Yan Q, Chou J, Yang Z, Tian D. Developed and developing world contributions to climate system change based on carbon dioxide, methane and nitrous oxide emissions. Adv Atmos Sci. 2016;33(5):632-43.

18. Climate and clean air coalition. Methane. (no date). https://www.ccaco alition.org/en/slcps/methane. Accessed 14 June 2020.

19. van Amstel AR, Swart RJ. Methane and nitrous oxide emissions: an introduction. Fertilizer Research. 1994;37:213-25.

20. Borunda A. Methane, explained. National Geographic. January 232019. https://www.nationalgeographic.com/environment/global-warming/ methane/. Accessed: 14 June 2020.

21. Smith KA. The impact of agriculture and other land uses on emissions of methane and nitrous and nitric oxides. Environ Sci. 2005;2(2-3):101-8.

22. Yusuf RO, Noor ZZ, Abba AH, Hassan MA, Din MF. Methane emission by sectors: a comprehensive review of emission sources and mitigation methods. Renew Sustain Energy Rev. 2012;16(7):5059-70.

23. Arantes $R$, Welch JR, Tavares FG, Ferreira AA, Vettore MV, Coimbra CEA Jr. Human ecological and social determinants of dental caries among the Xavante Indigenous people in Central Brazil. PLoS ONE. 2018;13(12):e0208312.

24. Jia Y, Li Z, Liu C, Zhang J. Methane medicine: a rising star gas with powerful anti-inflammation, antioxidant, and antiapoptosis properties. Oxid Med Cell Longev. 2018;2018:1912746.

25. Gerber JS, Carlson KM, Makowski D, et al. Spatially explicit estimates of $\mathrm{N}_{2} \mathrm{O}$ emissions from croplands suggest climate mitigation opportunities from improved fertilizer management. Glob Change Biol. 2016. https:// doi.org/10.1111/gcb.13341.

26. Ravishankara AR, Daniel JS, Portmann RW. Nitrous oxide (N2O): The dominant ozone-depleting substance emitted in the 21 st century. Science. 2009:326(5949):123-5.
27. Höhne N, Blum H, Fuglestvedt J, et al. Contributions of individual countries' emissions to climate change and their uncertainty. Climatic Change. 2011;106(3):359-91.

28. Butterbach-Bahl K, Baggs EM, Dannenmann M, Kiese R, Zechmeister-Boltenstern S. Nitrous oxide emissions from soils: how well do we understand the processes and their controls? Philos Trans R Soc Lond B Biol Sci. 2013;368(1621):20130122.

29. Gould SE. What makes things acid: The pH scale. Scientific America. December 3 2012. https://blogs.scientificamerican.com/lab-rat/whatmakes-things-acid-the-ph-scale/. Accessed: 13 June 2020.

30. Chemistry Libretexs. Oxides. June 5 2019. https://chem.libretexts.org/ Bookshelves/Inorganic_Chemistry/Modules_and_Websites_(Inorg anic_Chemistry)/Descriptive_Chemistry/Main_Group_Reactions/Compo unds/Oxides. Accessed 12 June 2020

31. Nascimento MM, Gordan W, Garvan CW, Browngardt CM, Burne RA. Correlations of oral bacterial arginine and urea catabolism with caries experience. Oral Microbiol Immunol. 2009;24(2):89-95.

32. Schreiber $F$, Stief $P$, Gieseke $A$, et al. Denitrification in human dental plaque. BMC Biol. 2010;8:24.

33. Hsieh JJ. Ecological inferential fallacy. (No date). https://www.britannica .com/science/ecological-fallacy. Accessed 6 March 2020.

\section{Publisher's Note}

Springer Nature remains neutral with regard to jurisdictional claims in published maps and institutional affiliations.
Ready to submit your research? Choose BMC and benefit from:

- fast, convenient online submission

- thorough peer review by experienced researchers in your field

- rapid publication on acceptance

- support for research data, including large and complex data types

- gold Open Access which fosters wider collaboration and increased citations

- maximum visibility for your research: over 100M website views per year

At BMC, research is always in progress.

Learn more biomedcentral.com/submissions 